\title{
The Effect of Teacher Professionalism and Principal Leadership on Teacher Performance
}

\author{
H. Husin ${ }^{1 *}$, Bukman Lian ${ }^{1}$, Mulyadi ${ }^{1}$ \\ ${ }^{1}$ Universitas PGRI Palembang \\ *Corresponding author. E-mail: bukmanlian@univpgri-palembang.ac.id
}

\begin{abstract}
This research was conducted with the aim of describing the effect of teacher professionalism and principal leadership on the performance of state high school teachers in Ogan Komering Ilir Regency, either partially or simultaneously. This research was conducted by following the flow of quantitative research. The results obtained from this study are that teachers professionalism has a positive and significant effect on teacher performance partially. Likewise, the leadership of the principal also has a positive and significant effect on teacher performance. Simultaneously, teachers professionalism and principal leadership have a positive and significant effect on the performance of public high school teachers in Ogan Komering Ilir Regency.
\end{abstract}

Keywords: Teacher Professionalism, Principal Leadership, Teachers’ Performance

\section{INTRODUCTION}

A professional attitude is an attitude that must be owned by anyone. A person's professional attitude will help them complete their duties and obligations properly. Professional means being able to do everything in accordance with their authority. Someone who is capable of being professional in carrying out a task is believed to have a high success rate.

A person's professional job cannot be called a career in the strictest sense. Professional is a term for anyone who provides services or services in compliance with protocols and regulations in the sector they work in in exchange for a salary [1]. The person is also a member of a legal entity or association created by a country or region's laws. Even so, anyone who is a specialist in a field is often referred to as a "professional" in that field, even though he is not a member of a legally recognized organization.

A profession is a job that needs specialized training and information mastery [2]. A professional organization, code of ethics, and qualification and licensing procedures unique to that specialty are normally present.

From this definition, it is clear that the use of the words professional and profession can be distinguished. As a job that requires special skills and is obtained through special education and training, it is called a profession. And people who do work and work in professions are known as professionals. Although it is important to understand that professionals can also be pinned on people who do not work in the professional field, but are able to do their job well.

Teachers are professional educators with the main task of educating, teaching, guiding, directing, preparing, assessing, and evaluating students in education early childhood formal education, basic education, and secondary education, according to the Minister of Education and Culture Regulation Number 23 of 2017 concerning School Days, particularly in article 1 paragraph (3).

The affirmation of the professionalism of a teacher is also stated in Law Number 14 of 2005 concerning Teachers and Lecturers, especially in article 1 paragraph (1) it is stated that teachers are professional educators with the main task of educating, teaching, guiding, directing, training, assessing, and evaluating students in early childhood education through formal education, basic education, and secondary education [3].

The form of teacher professionalism that can be optimized is by mastering the main competencies, such as pedagogical competence, personality competence, social competence and professional competence. If this can be done well by the teacher, it is assumed that the teacher's performance will be even better. In order to support the improvement of teacher performance, of course many other factors also play a role, including the leadership in schools.

Principal leadership is assumed to have an impact on teacher performance. That is why, this factor also needs 
to be considered by schools as an institution. A study reported that the leadership of a school principal has an impact on teacher performance by $15.7 \%$ [4].

The principal's duty is to provide a positive influence, provide encouragement to be better, provide guidance in carrying out tasks, carry out directions, and become a driving force for teachers, education staff, students, parents as well as interested parties to work and participate in achieving the stated goals [5].

Everyone has their own way of leading. The differences that occur between leaders can be caused by many factors including external (outside) and internal (inside) factors. Internal factors are more to the nature and behavior of the leader himself, while there are many external factors, including because of the social environment where the leader lives or colleagues at school, each leadership has its own environment, meaning that leadership will run effectively if the situation and conditions support that leadership. .

Seeing the importance of leadership or managerial ability to performance, it is necessary to have a leader who can really carry out their functions properly so that all parties in an organization (educational institutions) can carry out their duties properly [6]. A leader as a control has an important role in improving teacher performance so that it can have a positive impact on teacher performance in the academic field. In this case the researcher wants to focus on teacher professionalism and leadership held by the principal in order to improve the performance of public high school teachers in Ogan Komering Ilir district.

The principal as a leader must be able to motivate teachers and administrative staff by providing or inspiring creativity in carrying out their work. The principal in his leadership must be able to practice the vision and mission, be able to empower the potential in the school as an educational institution organization through adjusting the way of thinking or the perspective of all things, developing a vision and mission through the use of the talents, expertise, technical skills and abilities contained in the resources. school power. Leadership and leadership are two things that are difficult to separate. However, both have different meanings from one another. One thing is clear, leadership is a form of behavior (style) which is a result of interaction.

A leader in a school is expected to have the ability to determine future direction through a clear vision and mission in achieving predetermined goals. Through a preliminary study conducted by researchers, several things were identified as preliminary findings for further research. Among these findings, the teacher's performance is uneven, as well as everyone having a way of leading their school.

The assessment will be subjective if empirical evidence is not carried out, such as the perception of the dictatorship of the principal in leading the school. This was known by the researcher when conducting a direct review at the research location. Likewise, with the assumption that a teacher is declared not to have a good performance, these assumptions are increasingly developing among teachers. Therefore, researchers believe that these things are related. To prove this, the researcher must conduct an in-depth study.

\section{METHODS}

This When the research was started from July 2020 to September 2020. The research was conducted at a public high school in Ogan Komering Ilir Regency. This research is carried out on objects related to education; therefore, it can also be stated as research whose approach is through educational research methods. Educational research method is a method used to describe phenomena that occur in education [7]. This type of research used in this research is descriptive quantitative research. Descriptive research is a form of research carried out with the aim of knowing the existence of independent variables, either in one particular variable or even more than one variable, without making a comparison or connecting with other variables [8]. It is meant as an independent variable, which is an independent variable and not an independent variable, because if the variable is independent it will always be paired with the dependent variable.

In connection with the research method used is a quantitative research method, the results of the analysis described are derived from quantitative data. Quantitative research is a study that obtains data in the form of numbers or it can be extrapolated qualitative data [8], [9]. A quantitative approach is used to measure the variables in this study, namely the variables $\mathrm{X} 1, \mathrm{X} 2$ and $\mathrm{Y}$ and then look for the relationship between these variables.

The population in this study was 563 people, so the researchers used a sample of 177 people obtained through purposive sampling technique. The research data were obtained through questionnaires and documentation, which were then analyzed through parametric statistics.

\section{RESULTS AND DISCUSSION}

The data obtained from the implementation of the research had been tested for prerequisites, and it was stated that the data were normally distributed and there were no symptoms of heteroscedasticity. For this reason, hypothesis testing can be done with parametric statistics through simple and multiple linear regression tests.

Testing the first hypothesis is a test to prove whether there is an effect of teacher professionalism on teacher performance. The t-count value is 12.495 and is significant at 0.000 . If it is seen from the significance value, it is stated that there is a positive and significant influence of teacher professionalism on the performance of SMA Negeri teachers in Ogan Komering Ilir Regency. The statement is in accordance with the criteria in testing, that the alternative hypothesis (Ha) is 
accepted if the significance is $<0.05$. It can also be seen through tcount $=12.495>$ ttable $=1.974$

The correlation coefficient is $68.7 \%$ and belongs to the category of a close relationship between teacher professionalism and the performance of public high school teachers in Ogan Komering Ilir Regency. The determinant coefficient or the amount of influence has a value of 0.472 , which means that $47.2 \%$ of teacher performance is influenced by teacher professionalism, if the test is carried out individually.

The second hypothesis testing is hypothesis testing using simple linear regression analysis on the principal's leadership variable on teacher performance. The t-count value obtained is 10.420 and is significant at 0.000 . This means that there is a positive and significant effect of school principal leadership on the performance of public high school teachers in Ogan Komering Ilir Regency. The statement is in accordance with the criteria in testing, that the alternative hypothesis ( $\mathrm{Ha}$ ) is accepted if the significance $<0.05$. It can also be seen through tcount $=10,420>$ ttable $=1,974$.

The correlation coefficient is $61.9 \%$ and belongs to the category of a close relationship between the leadership of the principal and the performance of the teachers of the State Senior High School in Ogan Komering Ilir Regency. The determinant coefficient of $38.3 \%$ of teacher performance is influenced by the leadership of the principal, if the test is carried out individually.

The third hypothesis testing is testing the hypothesis simultaneously or collectively. Taken together, it is meant that in this study there are two independent variables and one dependent variable, testing this third hypothesis simultaneously testing X1X2 against $\mathrm{Y}$. From the tests carried out, it is known that the Fcount value is 84.616 and compared to FTabel of 3.048, it is stated that the professionalism of teachers and leadership of the principal jointly has a positive and significant effect on the performance of public high school teachers in Ogan Komering Ilir district

The correlation coefficient or the magnitude of the relationship between the variables of teacher professionalism and principal leadership with the performance of state high school teachers in Ogan Komering Ilir Regency is $70.2 \%$ and is included in the close relationship category. Together or simultaneously the variables of teacher professionalism and principal leadership have an influence of $49.3 \%$ on the performance of public high school teachers in Ogan Komering Ilir Regency. As for other factors that influence it, it is not further analyzed in this study.

\section{The effect of teacher professionalism on teacher performance}

This study confirms that teacher professionalism has an impact on teacher performance. This means, the higher the professional level of the teacher, the more optimal the teacher's performance will be. The results of this study support a research finding conducted by Darlima [10], she found that teacher professionalism is able to have a positive and significant impact on teacher performance. Additionally, similar research also found by Rachmawati [11] that at SMK Batik 1 Surakarta it was stated that teacher professionalism could have a positive impact on teacher performance.

Moreover, Sumarno [12] also found that professionalism is able to affect the performance of public elementary school teachers in Paguyangan District, Brebes Regency. For this reason, these studies were conducted on different objects so as to be able to describe the consistency of the influence of teacher professionalism variables on teacher performance. That is what also happened in this study, that teacher professionalism was able to have a positive and significant effect on teacher performance in SMA Negeri in Ogan Komering Ilir Regency.

\section{The influence of principal leadership on teacher performance}

The results of testing this hypothesis strengthen some of the previous studies that have been conducted by Darlima [10] that the principal's leadership can actually affect the performance of teachers who teach. It is also similar to the results obtained by Sumarno [12] that it is very good if the leadership of the principal is perceived as good by the teacher, because it can optimize teacher performance.

The leadership of the principal has a very significant impact on teacher performance in particular, because all activities that occur in the school are under his or her authority [13]. It is no different from the research of Brahmasari \& Suprayetno [14] that good leadership by a principal is able to provide an important role for optimal performance.

In conclusion, it is important that the leadership of the principal is well executed and acceptable to every element of the school community [15], [16], [17], especially in this pandemic of covid 19 that causes anxiety among educators [18]. Because that is one of the factors that affect performance, it is highly expected that a school principal leads the school with principles that can be accepted by every school community.

\section{The influence of teacher professionalism and principal leadership on teacher performance}

Overall, the performance of teachers at SMA Negeri in Ogan Komering Ilir Regency is in the good category. However, it is important for teachers to continue to optimize their performance so that they can further improve the quality of education. The size of the influence which is quite high is appropriate, because if each independent variable is tested partially, the magnitude of the influence does not reach or equal to the test simultaneously. That means, it would be better if a teacher has a professional attitude embedded in his work, then supported by the leadership of the principal who is perceived as good. Therefore, education will be 
optimal if these variables are optimized for the future Regency.

\section{CONCLUSION}

The conclusion from the implementation of this research is that there is a positive and significant effect of teacher professionalism on teacher performance; there is a positive and significant influence of principal leadership on teacher performance; There is a positive and significant effect of teacher professionalism and principal leadership together on the performance of teachers of SMA Negeri teachers in Ogan Komering Ilir Regency. The magnitude of the influence together is $49.3 \%$.

\section{REFERENCES}

[1] Wikipedia. (2020). Profesional. Wikipedia.org: https://id.wikipedia.org/wiki/Profesional

[2] Wikipedia. (2020). Profesi. Wikipedia.org: https://id.wikipedia.org/wiki/Profesi

[3] Pemerintah Republik Indonesia. (2005). UndangUndang Nomor 14 Tahun 2005 tentang Guru dan Dosen. Jakarta: Pemerintah Republik Indonesia.

[4] Mutmainah. (2016). Pengaruh kepemimpinan kepala sekolah dan profesionalitas guru terhadap kinerja guru SMK Negeri 1 Tepus. Yogyakarta: Universitas Negeri Yogyakarta.

[5] Kristiawan, M., Safitri, D., \& Lestari, R. (2017). Manajemen pendidikan. Yogyakarta: Deepublish.

[6] Tobari. (2016). Membangun Budaya Organisasi pada Instansi Pemerintahan. Yogyakarta: Deepublish.

[7] Sukardi. (2011). Metodologi Penelitian Pendidikan. Jakarta: Bumi Aksara.

[8] Sugiyono. (2017). Metode Penelitian Kualitatif, Kuantitatif dan $R \& D$. Bandung: Alfabeta.

[9] Narimawati, U. (2008). Metodologi penelitian kualitatif dan kuantitatif, teori dan aplikasi. Bandung: Agung Media.

[10] Darlima. (2017). Pengaruh profesionalisme guru, kepemimpinan kepala sekolah dan budaya organisasi terhadap kinerja guru di SMP Negeri 14 Palembang. Jurnal Ecoment Global, volume 2 nomor 2, 63-72.

[11] Racmawati, I. (2014). Pengaruh profesionalisme guru dan kepemimpinan kepala sekolah terhadap kinerja guru SMK Batik 1 Surakarta. Surakarta: Universitas Muhammadiiyah Surakarta.

[12] Sumarno. (2009). Pengaruh kepemimpinan kepala sekolah dan profesionalisme guru terhadap kinerja guru sekolah dasar negeri di Kecamatan Paguyangan Kabupaten Brebes. Semarang: Universitas Negeri Semarang.

[13] Septiana, R., Ngadiman, \& Ivada, E. (2013). Pengaruh Kepemimpinan Kepala Sekolah dan Motivasi Kerja terhadap Kinerja Guru SMP Negeri Wonosari. Jurnal Pendidikan Ekonomi, Volume 2 Nomor 1 .

[14] Brahmasari, I. A., \& Suprayetno, A. (2008). Pengaruh Motivasi Kerja, Kepemimpinan, dan Budaya Organisasi Terhadap Kepuasan Kerja Karyawan serta Dampaknya pada Kinerja Perusahaan (Studi Kasus pada PT. Pei Hei International Wiratama Indonesia) . Jurnal Manajamen dan Kewirausahaan Vol. 10, 124-135.

[15] Pratiwi, S. D. (2013). Pengaruh motivasi kerja, kepuasan kerja, kepemimpinan kepala sekolah menurut persepsi guru, dan iklim sekolah terhadap kinerja guru ekonomi SMP Negeri di Kabupaten Wonogiri. Jurnal Pendidikan Insan Mandiri Vol. 1 No. $1,89-100$.

[16] Kosim, M. (2017). Pengaruh kepemimpinan kepala sekolah terhadap kinerja guru untuk mewujudkan mutu pembelajaran. Khazana Akademia, Volume 1 Nomor 1, 30-38.

[17] Hasan, D., Bachri, S., \& Hasanuddin, B. (2017). Pengaruh kepemimpinan kepala sekolah dan lingkungan kerja fisik terhadap kinerja guru SMA Negeri 1 Ampana. e-Jurnal Katalogs, Volume 5 Nomor 10, 75-81.

[18] Sujadi, E., Fadhli, M., Kamil, D., Sonafist, Y., Meditamar, M. O., \& Ahmad, B. (2020). An anxiety analysis of educators, students and parents facing the new normal era in education sector in indonesia. Asian Journal of Psychiatry, 53, 102226-102226. 